Mladen Manjak, potpukovnik, dipl. inž. Centar za KISIP GŠ VS Beograd

\section{DARC SERVIS KONVENCIONALNE FM RADIO-DIFUZIJE}

UDC: 621.396 .97

Rezime:

Konvencionalna FM radio-difuzija može ponuditi dodatne servise uz pomoć podnosioca smještenih u slobodnom dijelu osnovnog opsega multipleksiranog signala. U radu su prikazane osnovne karakteristike DARC servisa FM radio-difuzije i njegove moguće primjene.

Ključne riječi: FM radio-difuzija, DARC, referentna blok-šema, koder, dekoder, ram, protokol.

\title{
DARC SERVICE CONVENCIONAL FM RADIO BROADCASTING
}

Summary:

Conventional FM radio broadcasting can offer additional services by means of a subcarrier placed in a clear part of the beseband multiplex signal. This paper contains lementary characteristics of DARC service conventional FM radio broadcasting and possible applications.

Key words: FM broadcasting, DARC, reference model, encoder, decoder, frame, protocol.

\section{Uvod}

Odavno je uočeno da se konvencionalna FM radio-difuzija može iskoristiti za prenos dodatnih servisa pomoću podnosioca smještenih u slobodnom dijelu prenosnog kanala. Ovi servisi koriste digitalni signal koji sa osnovnim analognim audio signalom i uz pomoć frekvencijskog multipleksiranja formira kompozitni signal za emitovanje preko radio-difuzne mreže. Prvi takav servis bio je RDS (Radio Data System) koji koristi podnosilac na $57 \mathrm{kHz}$, a prenos informacije vrši se brzinom od $1,2 \mathrm{~kb} / \mathrm{s}$. Nastao je u Evropi gdje je doživio i najveću primjenu. Najviše se koristi kao podrška osnovnom audio servisu, ali i za slanje kratkih poruka različitih namjena. Prije desetak godina nastao je novi DARC (DAta Radio Channel) servis, razvijen $\mathrm{u}$ NHK laboratoriji (Japan), a standardizovali su ga ETSI i ITU-R. Servis je pogodan za aplikacije koje se odvijaju u realnom vremenu i po svojim performansama prevazilazi RDS, tako da ima mnogo širu primjenu.

\section{DARC}

DARC takođe koristi frekvencijsko multipleksiranje unutar slobodnog dijela FM radio-difuznog kanala. Za prenos digitalnog signala dodatne informacije koristi se podnosilac na $76 \mathrm{kHz}$. Sam postupak formiranja multipleksa ne smije da ometa prenos osnovne informacije, što predstavlja najvažniji uslov da bi se ova 


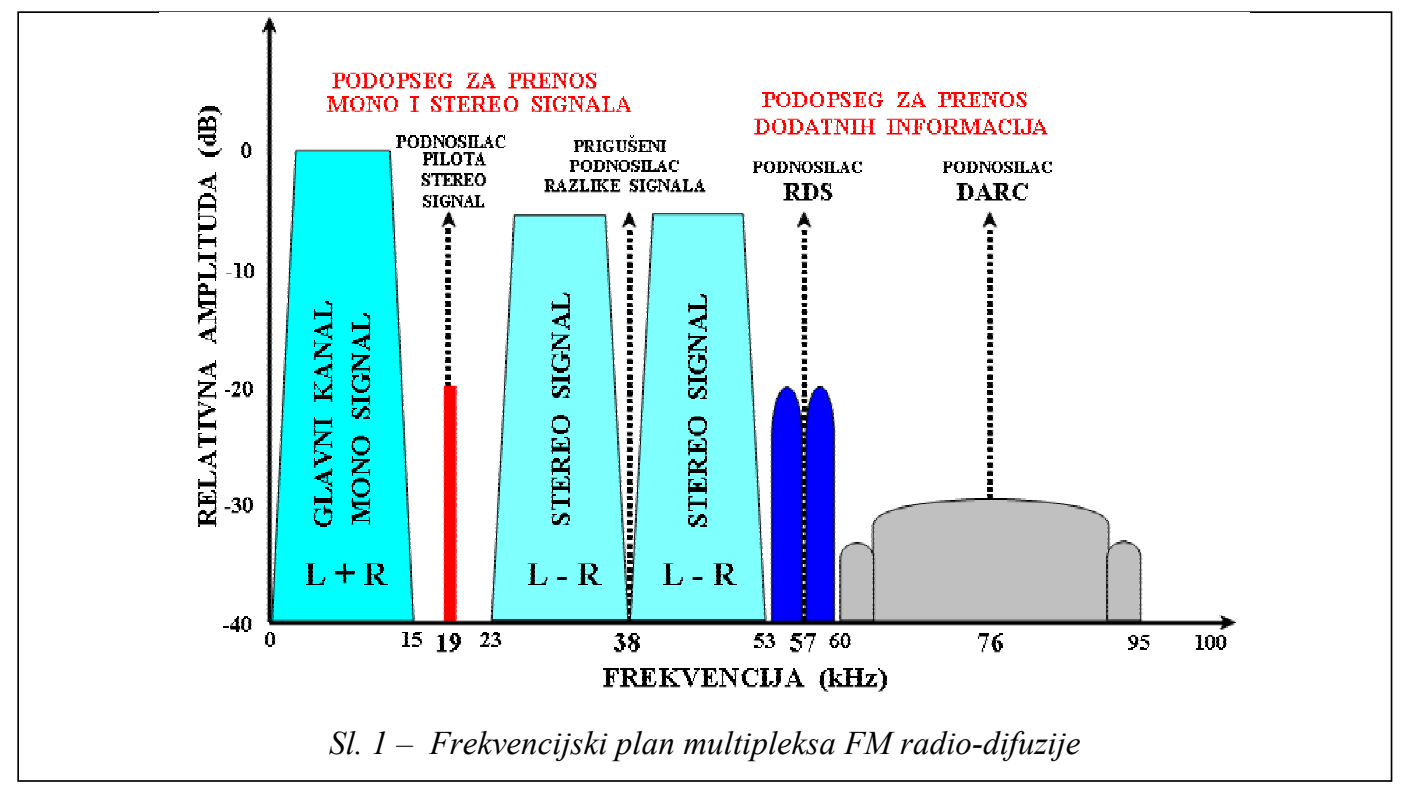

tehnika mogla primjeniti. Na slici 1 prikazan je frekvencijski plan multipleksa jednog standardnog FM predajnika koji, pored osnovnog mono i stereo audio signala, emituje i RDS i DARC signale. Od $100 \mathrm{kHz}$, kolika je širina osnovnog kanala, za prenos audio signala potrebno je 53 $\mathrm{kHz}$, dok je ostali dio kanala slobodan.

Brzina prenosa digitalnog DARC signala je $16 \mathrm{~kb} / \mathrm{s}$. Prenos se vrši u paketima, gdje polovina osnovnog protoka otpada na formiranje rama i kontrolu grešaka prenosa, a drugu polovinu predstavlja korisna informacija. Podnosilac signala formira se kao četvrti harmonik osnovnog pilot signala frekvencije 19 kHz. Prenos informacije vrši se do korisnika koji mogu da imaju mobilni, portabl ili stacionarni prijemnik sa DARC dekoderom. Primjena DARC servisa je raznovrsna i može se koristiti za prenos različitih servisa, kao što su digitalne poruke, datoteke, faks poruke, elektronska pošta, elektronske novine, vijesti, tačno vrijeme, meteorološki podaci, diferencijalna korekcija za GPS, telemetrijski podaci, upravljački signali, zvučne poruke, itd. U Evropi, SAD i Japanu realizovane su brojne DARC mreže koje podržavaju prethodno navedene servise.

\section{Struktura DARC mreže}

DARC je definisan standardima EN300751 (ETSI) [1], BS.1194, BS.641 i BS.412 (ITU-R). Slika 2 prikazuje referentnu strukturu DARC mreže koja sadrži servere davaoca servisa (Provider Service) SPSn, servere mreže NWSn, opremu predajnika (kodere) TSEn, korisničke prijemnike (dekodere) RECn i prenosne veze (linkove) TLn. U osnovnom modelu mreže informacija polazi od servera davaoca servisa ka serveru mreže gdje se vrši njeno objedinjavanje sa drugim informacijama, odnosno servisima. Potom se one distribuiraju ka predajnicima FM radio-difuzije koji radio-putem emituju informacije prema 


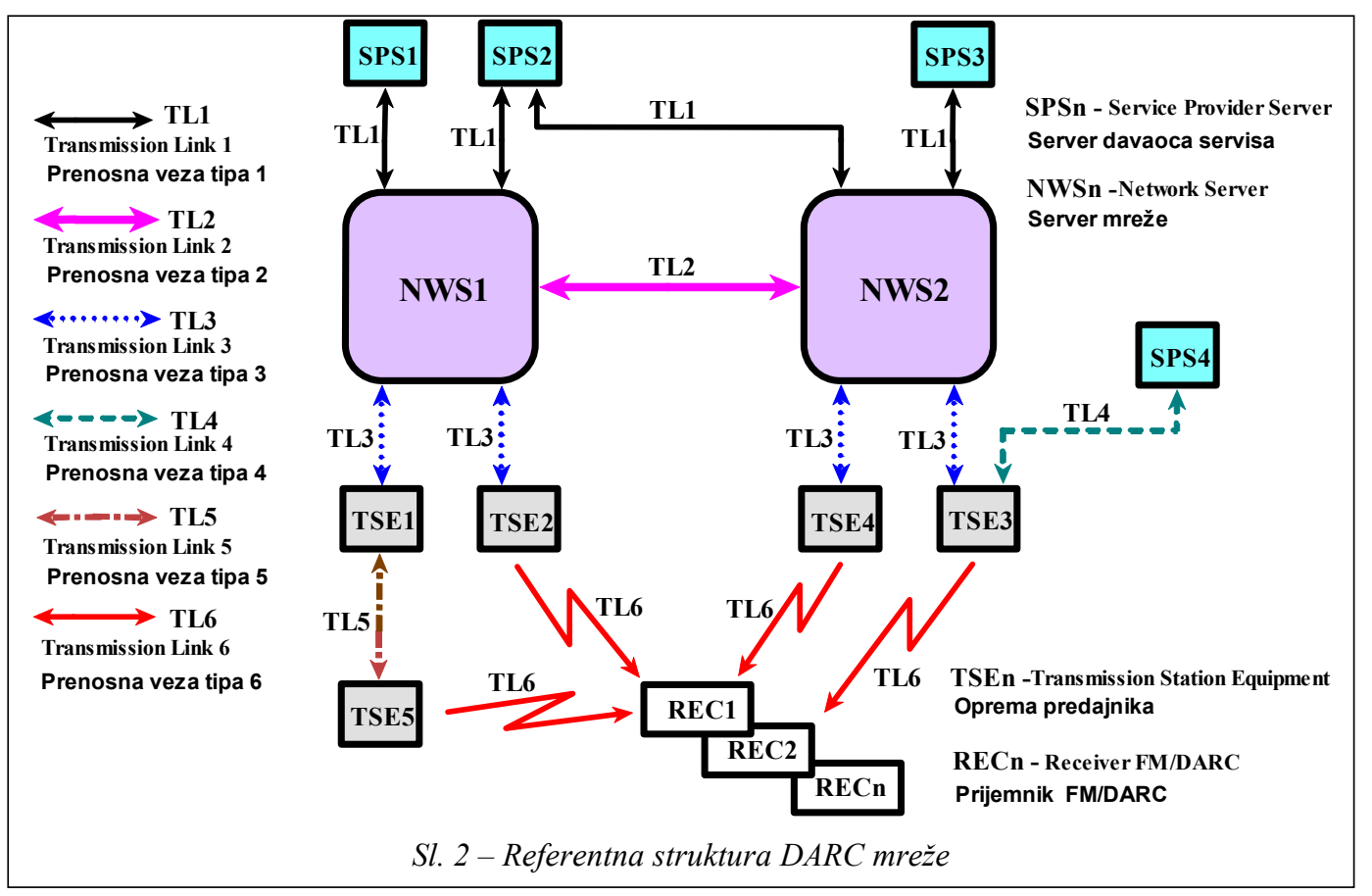

krajnjim korisničkim prijemnicima. Pored navedenog modela moguća je komunikacija između više servera mreža, ali i direktna veza servera davaoca servisa sa predajnicima. Na slici 3 prikazana je opšta blok-šema svih modela praktične realizacije DARC mreže. Pristup sistemu, odnosno serverima i radio-difuznim predajnicima najčešće se vrši pomoću TCP/IP protokola.

$\mathrm{Za}$ realizaciju ove mreže koriste se postojeći prenosni (najčešće radio-relejni) sistemi radio-difuznih organizacija ili javnih telekomunikacionih sistema. Na FM radio-difuznim predajnicima umjesto postojećih stereo kodera koriste se DARC koderi koji omogućavaju formiranje kompozitnog signala osnovnog i dodatnih servisa. Pored navedenog postupka prenosa postoji mogućnost primjene radio-repetitora za retransmisiju emitovanog kompozitnog signala. U tom slučaju radio-difuzni repetitor umjesto DARC kodera koristi kontrolno-mjerni prijemnik osnovnog opsega, koji prima od susjednih FM predajnika kompozitni (audio+RDS+DARC) signal, a potom ga ponovo emituje na svojoj nosećoj frekvenciji. Na ovaj način isključuje se potreba za posebnim prenosnim telekomunikacionim sistemom. Radio-difuzne mreže sastoje se od dva tipa predajni$\mathrm{ka}$, i to od malog broja primarnih ili baznih predajnika velike snage $(1-100 \mathrm{~kW})$ sa kojima se vrši osnovno pokrivanje geografske zone radio-difuznim signalom i velikog broja repetitora male snage $(<1 \mathrm{~kW})$ sa kojima se vrši korekcija osnovnog pokrivanja. DARC koderi se u principu koriste samo na baznim predajnicima, dok se na radio-repetitorima koriste kontrolnomjerni prijemnici osnovnog opsega. Kod korisnika se nalazi poseban DARC prijemnik ili klasični FM prijemnik sa DARC dekoderom i procesorom, pomoću kojih se dekodira i prikazuje poslata informacija. 


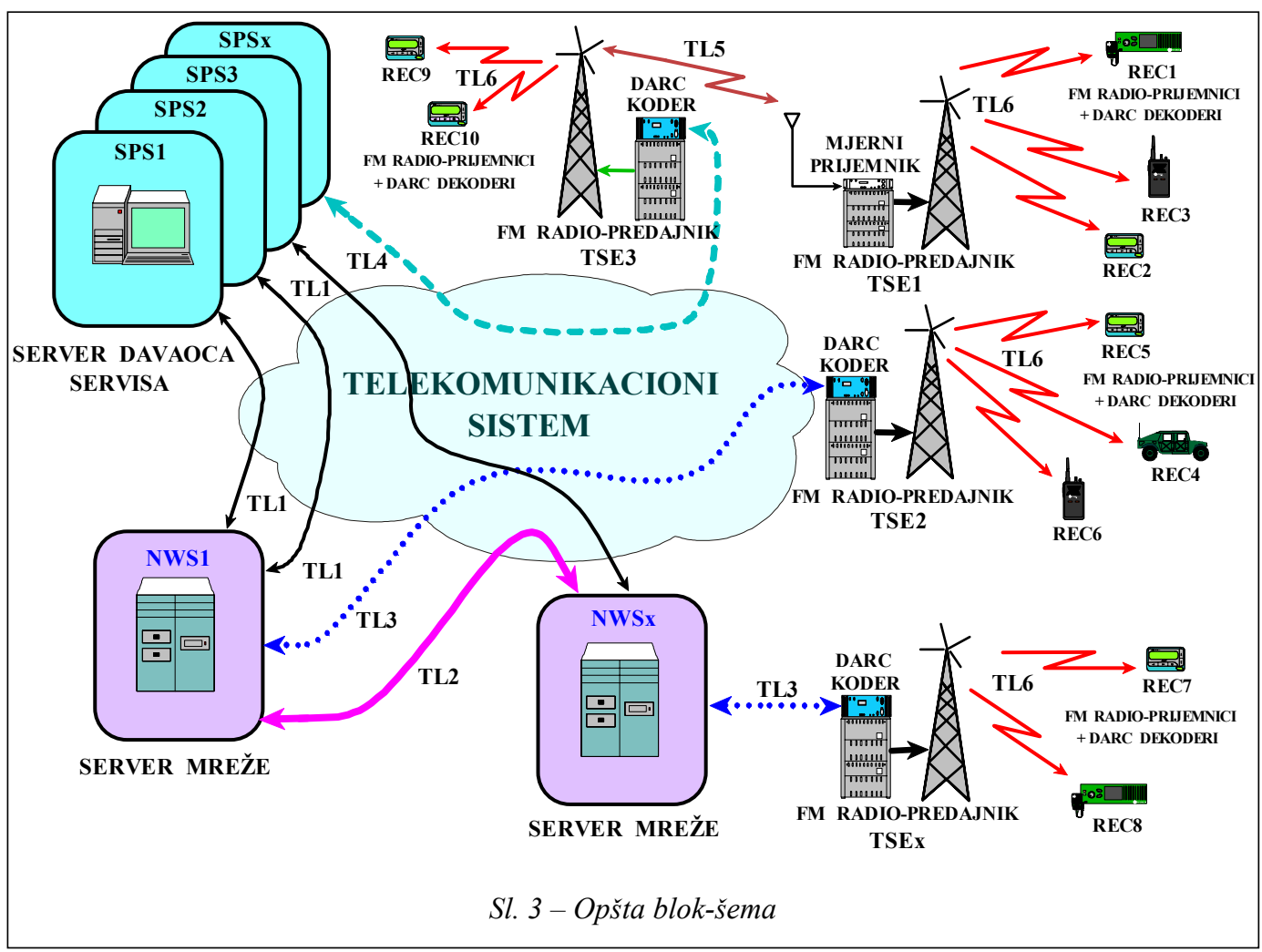

Zona prekrivanja DARC servisom zavisi od sledećih parametara: zone prekrivanja FM radio-difuzne mreže; zadatog nivoa bitske greške na prijemu; osjetljivosti prijemnika.

Po standardima ITU-R Rec. 412-5 definisana je jačina prijemnog polja za stereofonski prenos FM radio-difuzije zavisno od sredine i to: $-54 \mathrm{~dB} \mu \mathrm{V} / \mathrm{m} \mathrm{u}$ ruralnim sredinama; $-66 \mathrm{~dB} \mu \mathrm{V} / \mathrm{m}$ u urbanim sredinama; $-74 \mathrm{~dB} \mu \mathrm{V} / \mathrm{m}$ u velikim gradskim sredinama.

$\mathrm{Za}$ prijem, odnosno detekciju DARC signala zahtjeva se da na ulazu prijemnika odnos S/N FM signal bude jednak ili veći od $23 \mathrm{~dB}$ za BER od $10^{-2}$ (za digitalni signal bez zaštite). Osjetljivost danas komercijalno dostupnih prijemnika nije manja od $-90 \mathrm{dBm}$.

Logička organizacija DARC-a zasnovana je na referentnom OSI modelu sa pet slojeva (slika 4), gdje je prikazan cjelokupan tok informacije od izvora do korisnika. Kroz DARC se mogu prenositi kratke i duge poruke grupisane $u$ četiri logička kanala sa različitim nivoom kodne zaštite. Ova osnovna zaštita izvodi se na nivou organizacije rama. Ramovi su grupisani na četiri načina. Kroz sistem se mogu prenositi poruke informacija koje se odvijaju u realnom ili vanrealnom vremenu. Tok informacije kroz slojeve odvija se na osnovu definisanih pravila, odnosno protokola i u većini je softverski podržan. Jedino fizički sloj ima posebnu hardversku realizaciju. 


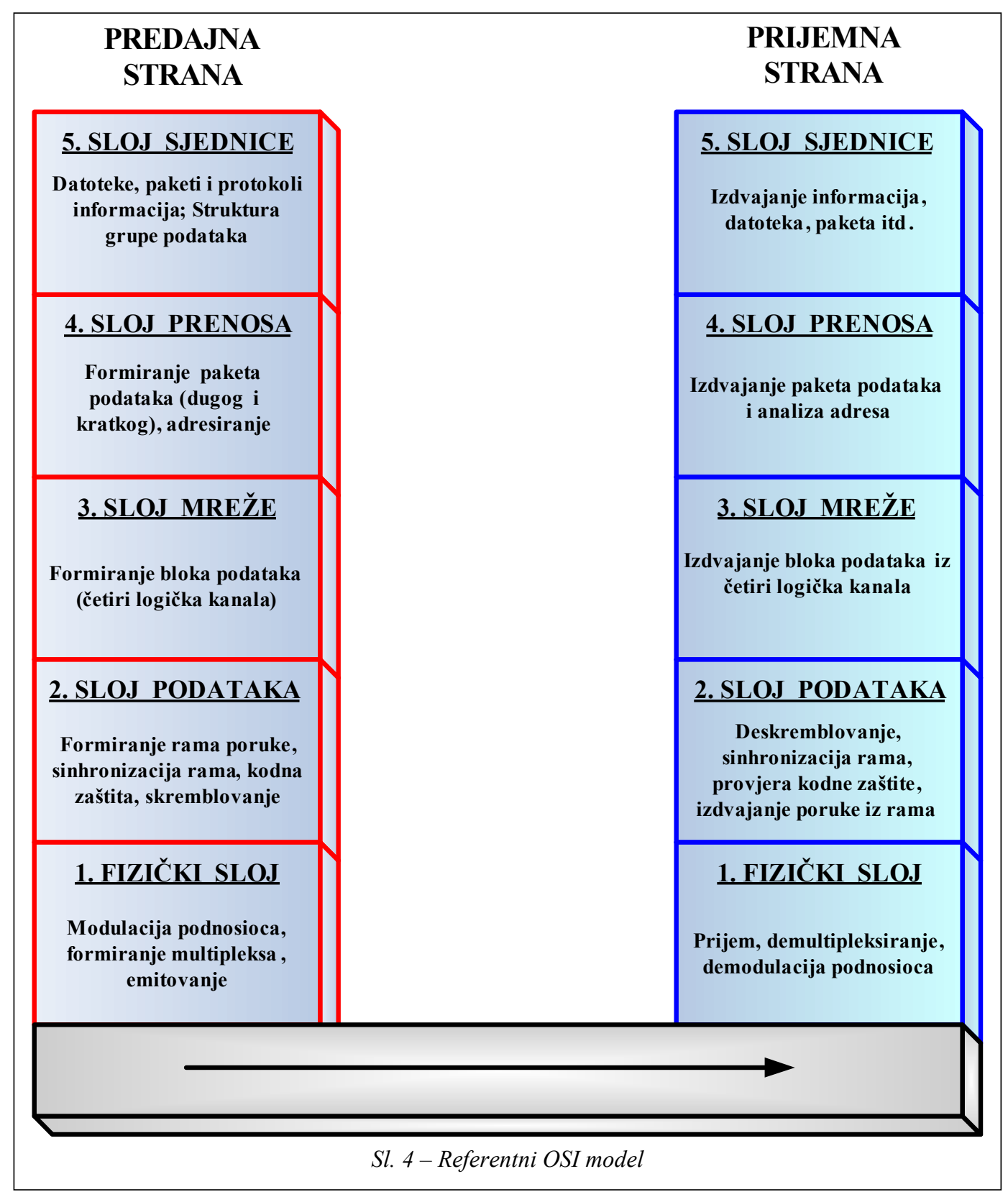

\section{DARC slojevi}

Fizički sloj (1. sloj)

$\mathrm{Na}$ predajnoj strani se digitalnim signalom, formiranim pomoću protokola prethodnih viših slojeva, vrši modulacija
DARC podnosioca koji se pridodaje ukupnom FM multipleksnom signalu na radio-difuznom predajniku. Na prijemnoj strani prvo se vrši demultipleksiranje (izdvajanje DARC-a) iz primljenog FM signala, a potom demodulacija prenesene 


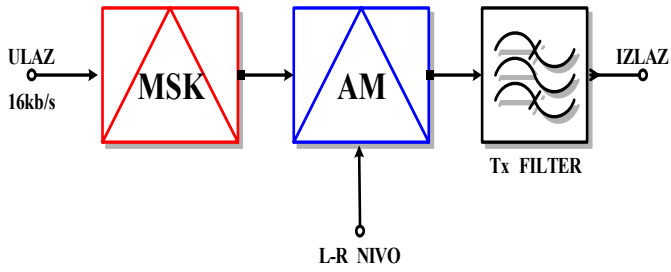

Sl. 5 -Blok-šema modulatora

Tabela 1

\begin{tabular}{|c|c|}
\hline & GORNJA GRANICA (sivo) \\
\hline$-60 \mathrm{~dB}$ & (frekvencija $<56 \mathrm{kHz}$ i $100 \mathrm{kHz} \leq$ frekvencija) \\
\hline$-40 \mathrm{~dB}$ & $\begin{array}{c}(56 \mathrm{kHz} \leq \text { frekvencija }<58 \mathrm{kHz} \text { i } 97 \mathrm{kHz} \leq \text { frekvenci- } \\
\mathrm{ja}<100 \mathrm{kHz})\end{array}$ \\
\hline$-20 \mathrm{~dB}$ & $\begin{array}{l}(58 \mathrm{kHz} \leq \text { frekvencija }<60 \mathrm{kHzi} 94 \mathrm{kHz} \leq \text { frekvenci- } \\
\mathrm{ja}<97 \mathrm{kHz})\end{array}$ \\
\hline $0,5 \mathrm{~dB} \quad(60 \mathrm{kHz} \leq$ frekvencija $<94 \mathrm{kHz})$ \\
\hline \multicolumn{1}{c|}{ DONJA GRANICA (bijelo) } \\
\hline$-0,5 \mathrm{~dB} \quad(64 \mathrm{kHz} \leq$ frekvencija $<88 \mathrm{kHz})$ \\
\hline
\end{tabular}

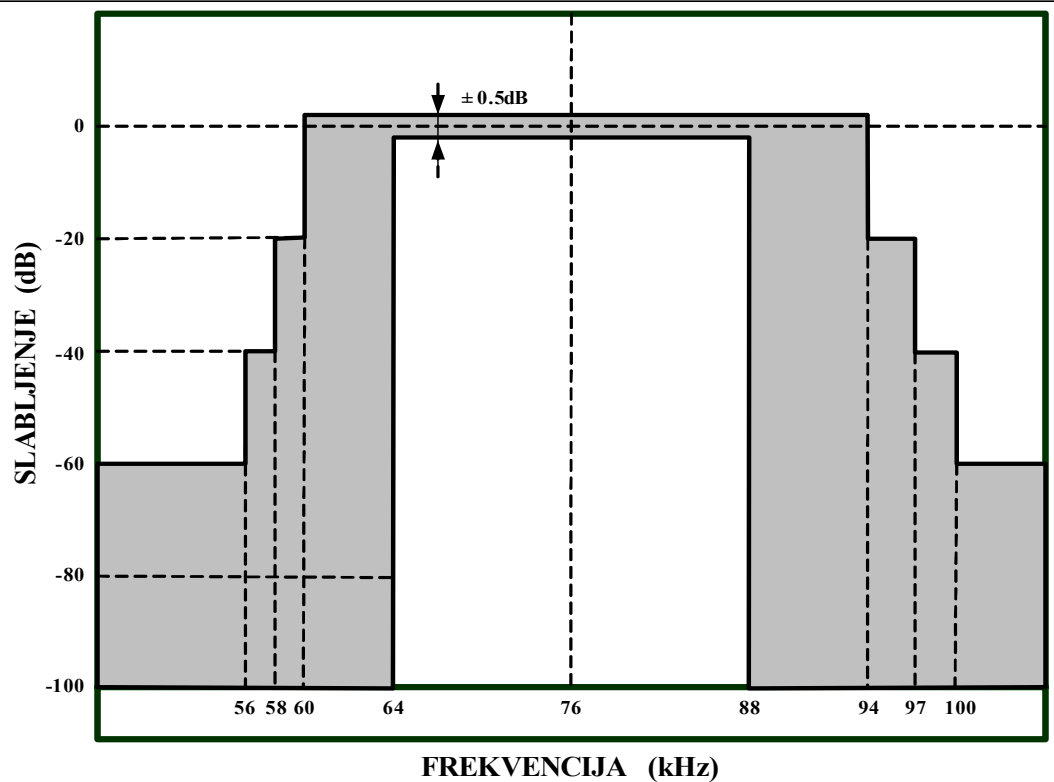

Sl. 6-Karakteristika Tx-filtera

informacije i njeno prenošenje na naredni sloj 2. Podnosilac je frekvencije $76 \mathrm{kHz}$ koja predstavlja fazno usklađeni četvrti harmonik pilot signala $(19 \mathrm{kHz})$ stereo prenosa. Stabilnost frekvencije podnosioca je $76 \mathrm{kHz} \pm 7,6 \mathrm{~Hz}(0,01 \%)$, a fazna razlika nije veća od $\pm 5^{\circ}$ od faze pilot signala. Modulacija podnosioca je LMSK (Level-controlled Minimum Shift Keying) tipa sa uobličavanjem spektra prema slici 6 i tabeli 1. Na slici 5 prikazana je blok-šema modulatora. LMSK se formira MSK modulacijom ulaznog digitalnog signala i kontrolom amplitude podnosioca nivoom signala razlike $(\mathrm{L}-\mathrm{R})$ stereo prenosa. Frekvencijski pomak podnosioca za logičku „1“ ulaznog digitalnog signala je $76 \mathrm{kHz}+4 \mathrm{kHz}$, a za logičku ,0“ je $76 \mathrm{kHz}-4 \mathrm{kHz}$.

$\mathrm{Na}$ slici 7 prikazan je dijagram promjene nivoa DARC podnosioca $u$ funkciji promjene nivoa signala razlike $(\mathrm{L}-\mathrm{R})$ stereo prenosa. Uočavaju se dvije granice, jedna na nivou $4 \%$ (devijacija podnosioca \pm 3 kHz) za devijaciju glavnog FM nosioca koja uzrokuje promjenu nivoa signala razlike (L-R) za $\leq 2,5 \%$ i druga na nivou $10 \%$ (devijacija podnosioca $\pm 7,5 \mathrm{kHz}$ ) za devijaciju glavnog FM nosioca koja uzrokuje promjenu nivoa signala razlike (L-R) za $\geq 5 \%$. Između ove dvije granice promjene unesenog nivoa i devijacije su linearne. 


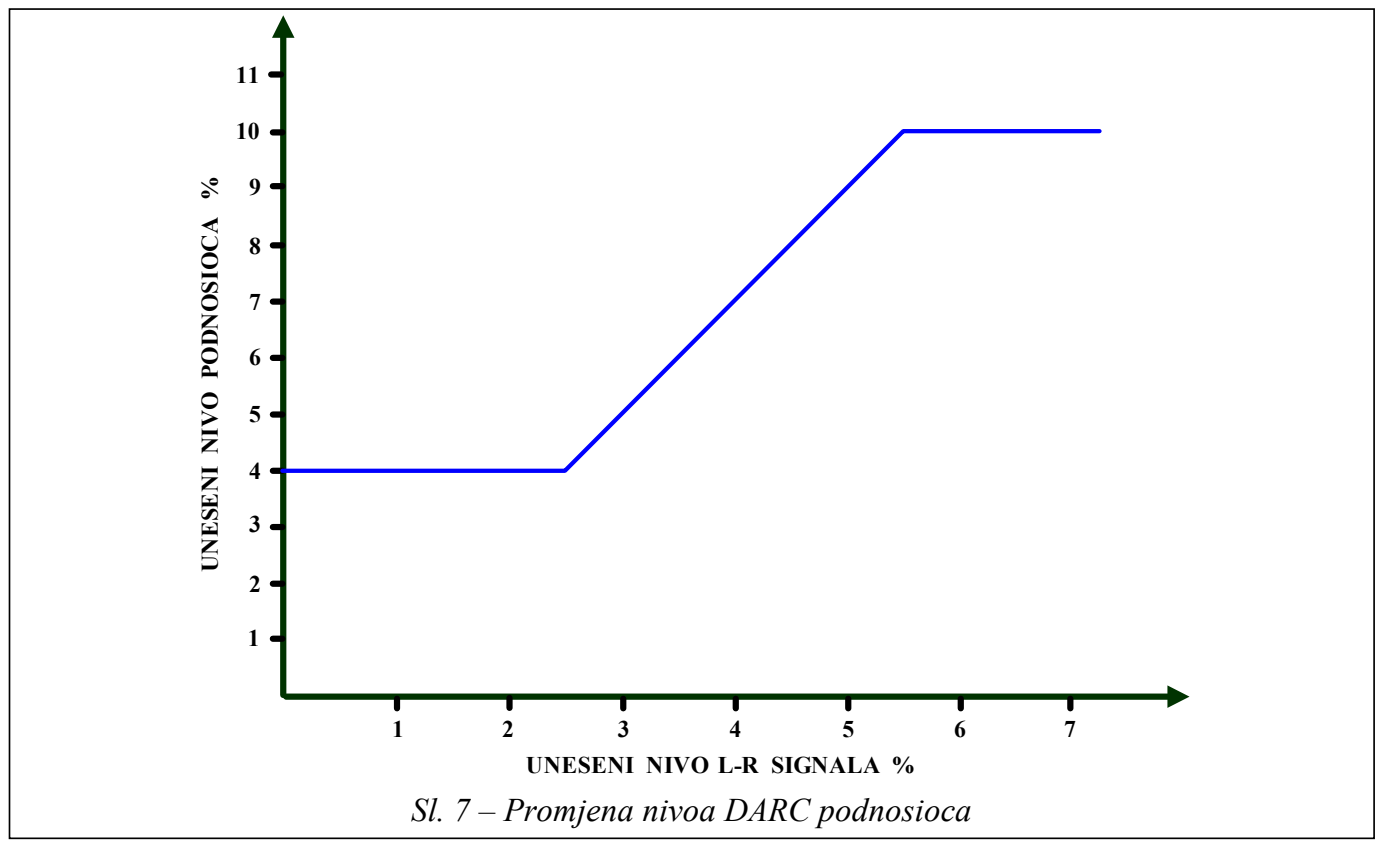

Ovo je vrlo bitna karakteristika, jer indirektno definiše kvalitet prenosa multipleksnog FM signala. Na mjestu prijema javlja se interferencija između audio signala i signala podataka zbog višestruke propagacije, pa se uvodi regulacija nivoa DARC podnosioca. Bitska brzina prenosa je $16 \mathrm{~kb} / \mathrm{s} \pm 1,6$ b/s. Širina DARC kanala za $-20 \mathrm{~dB}$ je 35 $\mathrm{kHz}$, a spektralna efikasnost prenosa [2] je $0,457 \mathrm{~b} / \mathrm{Hz}$. Korištenjem MSK modulacije postižu se dobre performanse prenosa u prisustvu šuma i pored niske spektralne efikasnosti. Zavisno od vrste poruke, odnosno tipa rama prenosa, kašnjenje signala kroz sistem kreće se od 0,018 do 4,914 sekundi. $\mathrm{Na}$ osnovu istih parametara efektivna bitska brzina prenosa informacije kreće se od 6209 b/s do $9778 \mathrm{~b} / \mathrm{s}$.

\section{Sloj podataka (2. sloj)}

U sloju podataka na predajnoj strani se vrši: grupisanje podataka iz višeg sloja u odgovarajuće ramove, sinhronizacija ra- ma, kodna zaštita i skremblovanje poruke za fizički sloj. Na prijemnoj strani provodi se inverzan postupak. Zavisno od vrste informacije koja se prenosi, grupisanje podataka realizuje se u četiri različita rama (A0, A1, B, C) sa odgovarajućim brojem tzv. L2blokova. Ramovi A0, B i C sastoje se od 272 bloka (L2) sa po 288 bita, a ram A1 od 284 bloka sa 288 bita. Na slikama 8a, 8b, 8c i $8 d$ prikazana je struktura navedenih ramova sa osnovnim parametrima. L2-blokovi sastoje se od identifikacije BIC (Block Identification Code), informacionih blokova, CRC-a i paritetnih blokova (horizontalnih, vertikalnih ili kombinacija).

U DARC-u se primjenjuju višestruki mehanizmi kodne zaštite informacije. Oni su prisutni na svim slojevima OSI modela, osim na 1. sloju. Glavna zaštita realizuje se na nivou 2. sloja, gdje se primjenjuju CRC i blok-kodovi tipa:

- $(272,190) x(272,190) \Leftrightarrow$ horizontalni paritet)x(vertikalni paritet),

- $(272,190) \Leftrightarrow$ (horizontalni paritet). 


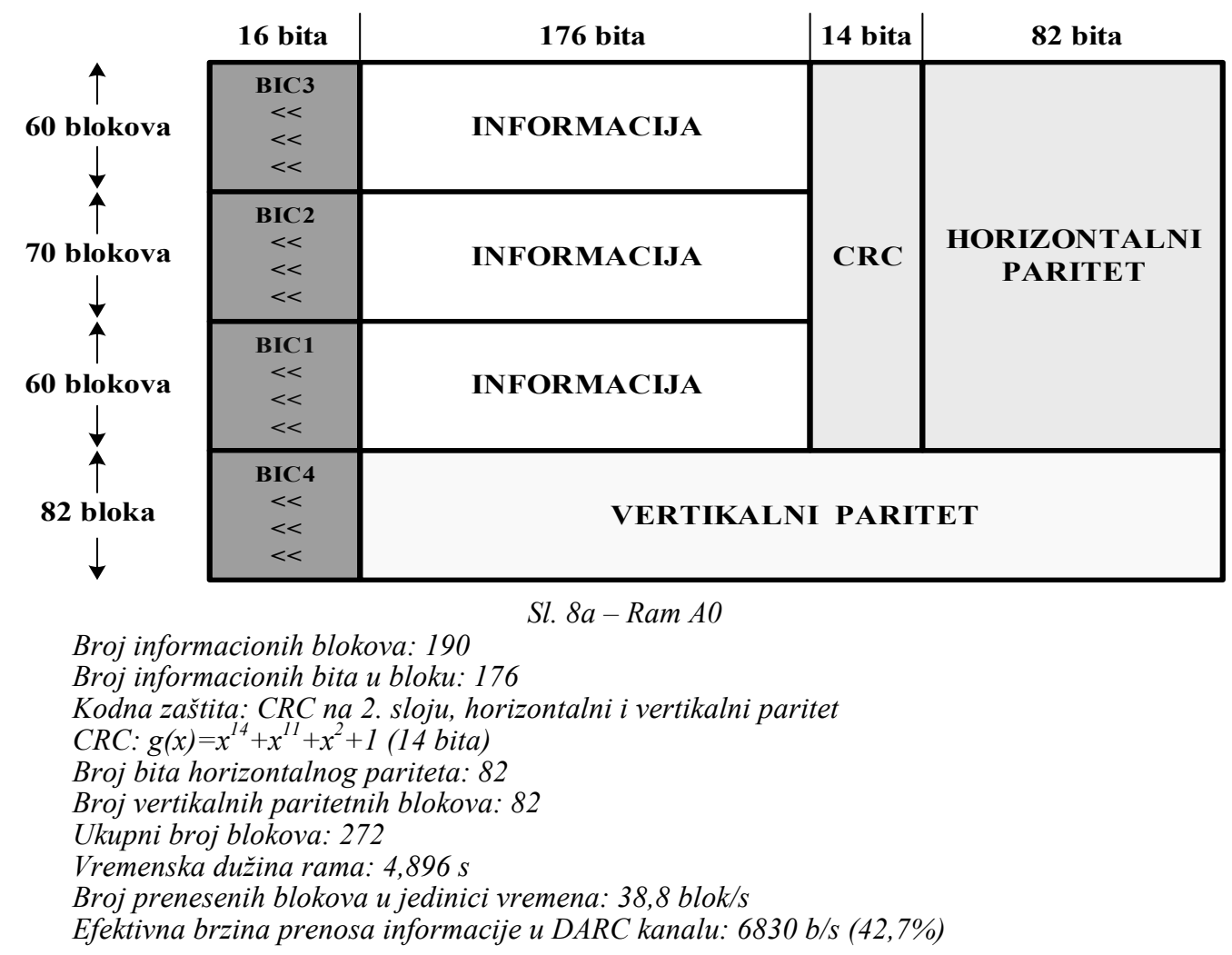

CRC je primjenjen uz svaki informacioni blok za sve četiri vrste rama, a generatorski polinom je tipa $\mathrm{g}(\mathrm{x})=\mathrm{x}^{14}+\mathrm{x}^{11}+\mathrm{x}^{2}+1$. Primjenjeni blok-kodovi razlikuju se zavisno od vrste rama koji se prenosi. $\mathrm{Za}$ ramove tipa A0, A1 i B koristi se tip $(272,190) \times(272,190)$, a za ram C tip $(272,190)$. Pri prenosu informacija u realnom vremenu koristi se samo CRC i blok kod horizontalnog pariteta tipa $(272,190)$. Ove informacije se prenose u ramovima A1 i C.

Generatorski polinom u blok kodu tipa $(272,190)$ je:

$\mathrm{g}(\mathrm{x})=\mathrm{x}^{82}+\mathrm{x}^{77}+\mathrm{x}^{76}+\mathrm{x}^{71}+\mathrm{x}^{67}+\mathrm{x}^{66}+\mathrm{x}^{56}+\mathrm{x}^{52}+$ $\mathrm{x}^{48}+\mathrm{x}^{40}+\mathrm{x}^{36}+\mathrm{x}^{34}+\mathrm{x}^{24}+\mathrm{x}^{22}+\mathrm{x}^{18}+\mathrm{x}^{10}+\mathrm{x}^{4}+1$.

To pruža mogućnost korekcije do 11 bita u poruci od 176 bita korisne

informacije. Što se tiče blok-koda $(272,190) \times(272,190)$ on obezbjeđuje skoro $100 \%$ zaštite do $3 \%$ grešaka od efektivne brzine prenosa informacije, a generalno dobru zaštitu do $7 \%$ grešaka. $\mathrm{Na}$ ostalim slojevima OSI modela $(3,4$. i 5) koristi se CRC o čemu će biti više riječi u narednom prikazu. U ramu B je primjenjena još i tehnika interlivinga sa vertikalnim paritetom. Prosječno kašnjenje prenosa blokova kod ramova je dato u tabeli 2 .

\begin{tabular}{|l|l|}
\hline Vrsta rama & \multicolumn{1}{|c|}{ Kašnjenje (s) } \\
\hline A0 & $0,018-1,494$ \\
\hline A1 & $\begin{array}{l}0,018-1,710 \text { (standardni prenos) } \\
0,018-0,396 \text { (prenos u realnom } \\
\text { vremenu) }\end{array}$ \\
\hline B & 4,914 \\
\hline C & 0,018 \\
\hline
\end{tabular}




\begin{tabular}{|c|c|c|c|c|}
\hline & 16 bita & 176 bita & 14 bita & 82 bita \\
\hline $\begin{array}{c}4 \\
60 \text { blokova } \\
\perp\end{array}$ & $\begin{array}{l}\text { BIC3 } \\
<< \\
<<\end{array}$ & INFORMACIJA & \multirow{3}{*}{ CRC } & \multirow{3}{*}{$\begin{array}{l}\text { HORIZONTALNI } \\
\text { PARITET }\end{array}$} \\
\hline $\begin{array}{c}\searrow \\
70 \text { blokova } \\
\downarrow\end{array}$ & $\begin{array}{l}\text { BIC2 } \\
<< \\
<<\end{array}$ & INFORMACIJA & & \\
\hline $\begin{array}{c}\uparrow \\
60 \text { blokova } \\
\downarrow\end{array}$ & $\begin{array}{l}\text { BIC1 } \\
<< \\
<<\end{array}$ & INFORMACIJA & & \\
\hline 22 bloka & $\underset{<<}{\text { BIC4 }}$ & \multicolumn{3}{|c|}{ VERTIKALNI PARITET } \\
\hline 4 bloka & BIC2 & $\begin{array}{l}\text { INFORMACIJA U REALNOM } \\
\text { VREMENU }\end{array}$ & CRC & PARITET \\
\hline 20 blokova & $\underset{<<}{\text { BIC4 }}$ & \multicolumn{3}{|c|}{ VERTIKALNI PARITET } \\
\hline 4 bloka & BIC2 & $\begin{array}{c}\text { INFORMACIJA U REALNOM } \\
\text { VREMENU }\end{array}$ & CRC & PARITET \\
\hline 20 blokova & $\underset{<<}{\text { BIC4 }}$ & \multicolumn{3}{|c|}{ VERTIKALNI PARITET } \\
\hline 4 bloka & $\mathrm{BIC2}$ & $\begin{array}{l}\text { INFORMACIJA U REALNOM } \\
\text { VREMENU }\end{array}$ & CRC & PARITET \\
\hline 20 blokova & $\underset{<<}{\text { BIC4 }}$ & \multicolumn{3}{|c|}{ VERTIKALNI PARITET } \\
\hline
\end{tabular}

Broj informacionih blokova: 202

Broj informacionih bita u bloku: 176

Kodna zaštita: CRC na 2. sloju, horizontalni i vertikalni paritet

Broj bita horizontalnog pariteta: 82

Broj vertikalnih paritetnih blokova: 82

Ukupni broj blokova: 284

Vremenska dužina rama: $5,112 \mathrm{~s}$

Broj prenesenih blokova u jedinici vremena: $39,5 \mathrm{blok} / \mathrm{s}$

Efektivna brzina prenosa informacije u DARC kanalu: 6954 b/s (43,4\%)

Za identifikaciju vrste blokova, kao i njihovu sinhronizaciju, koriste se četiri BIC (Block Identification Code) koda dužine 16 bita, koji imaju slabu međusobnu kros korelaciju. Skremblovanje se vrši pseudoslučajnom sekvencom definisanom polinomom $\mathrm{g}(\mathrm{x})=\mathrm{x}^{9}+\mathrm{x}^{4}+1$ i početnim stanjem 101010101. Skrembler se restartuje za svaki blok, s tim da se skremblovanje ne primjenjuje na BIC kod.

\section{Sloj mreže (3. sloj)}

U sloju mreže na predajnoj strani vrši se transformacija kratkih i dugih poruka (L4-poruke) iz višeg sloja prenosa u poruke (L3-blokove) grupisane u četiri logička kanala, dok se na prijemnoj strani vrši inverzan proces.

Logički kanali su: servisni kanal SeCh (Service Channel); kanal kratkih po- 


\begin{tabular}{|c|c|c|c|c|}
\hline & 16 bita & 176 bita & 14 bita & 82 bita \\
\hline 4 & BIC1 & INFORMACIJA 1 & CRC & PARITET \\
\hline 13 blokova & $<<$ & $<<$ & $<<$ & $<<$ \\
\hline$\downarrow$ & BIC1 & INFORMACIJA 13 & CRC & PARITET \\
\hline$\Delta$ & BIC3 & INFORMACIJA 14 & CRC & PARITET \\
\hline \multirow[b]{5}{*}{123 bloka } & BIC3 & INFORMACIJA 15 & CRC & PARITET \\
\hline & BIC4 & \multicolumn{3}{|c|}{ PARITET 1} \\
\hline & BIC3 & INFORMACIJA 16 & CRC & PARITET \\
\hline & BIC3 & INFORMACIJA 17 & CRC & PARITET \\
\hline & BIC4 & \multicolumn{3}{|c|}{ PARITET 2 } \\
\hline & BIC3 & INFORMACIJA 18 & CRC & PARITET \\
\hline & $<<$ & $<<$ & $<<$ & $<<$ \\
\hline & BIC4 & \multicolumn{3}{|c|}{ PARITET 40} \\
\hline & BIC3 & INFORMACIJA 95 & CRC & PARITET \\
\hline & BIC3 & INFORMACIJA 96 & CRC & PARITET \\
\hline$\downarrow$ & BIC4 & \multicolumn{3}{|c|}{ PARITET 41 } \\
\hline$\Delta$ & BIC2 & INFORMACIJA 97 & CRC & PARITET \\
\hline 13 blokova & $<<$ & $<<$ & $<<$ & $<<$ \\
\hline$\downarrow$ & BIC2 & INFORMACIJA 109 & CRC & PARITET \\
\hline \multirow{5}{*}{4} & BIC3 & INFORMACIJA 110 & CRC & PARITET \\
\hline & BIC3 & INFORMACIJA111 & CRC & PARITET \\
\hline & BIC4 & \multicolumn{3}{|c|}{ PARITET 42 } \\
\hline & BIC3 & INFORMACIJA 112 & CRC & PARITET \\
\hline & BIC3 & INFORMACIJA113 & CRC & PARITET \\
\hline \multirow{7}{*}{123 bloka } & BIC4 & \multicolumn{3}{|c|}{ PARITET 43} \\
\hline & BIC3 & INFORMACIJA 114 & CRC & PARITET \\
\hline & $<<$ & $<<$ & $<<$ & $<<$ \\
\hline & BIC4 & \multicolumn{3}{|c|}{ PARITET 81} \\
\hline & BIC3 & INFORMACIJA 189 & $\mathrm{CRC}$ & PARITET \\
\hline & BIC3 & INFORMACIJA 190 & CRC & PARITET \\
\hline & BIC4 & \multicolumn{3}{|c|}{ PARITET 82} \\
\hline
\end{tabular}

\section{Sl. $8 c-\operatorname{Ram} B$}

Broj informacionih blokova: 190

Broj informacionih bita u bloku: 176

Kodna zaštita: CRC na 2. sloju, horizontalni $i$ vertikalni paritet

CRC: $g(x)=x^{14}+x^{11}+x^{2}+1(14$ bita $)$

Broj bita horizontalnog pariteta: 82

Broj vertikalnih paritetnih blokova: 82

Ukupni broj blokova: 272

Vremenska dužina rama: 4,896 s

Broj prenesenih blokova u jedinici vremena: $38,8 \mathrm{blok} / \mathrm{s}$

Efektivna brzina prenosa informacije u DARC kanalu: $6830 \mathrm{~b} / \mathrm{s}$ (42,7\%)

ruka SMCh (Short Message Channel); koje omogućavaju korektno i sinhronizokanal dugih poruka LMCh (Long Messa- vano ponašanje prijemnika u DARC ge Channel); kanal izvornih blok- mreži. Kanal može da prenosi 16 vrsta -poruka BMCh (Block Message Channel). servisnih poruka. Svaka poruka sadrži od

Servisni kanal SeCh koristi se za 1 do 16 L3-blokova, čija veličina od 176 prenos mrežnih i servisnih informacija, bita odgovara informacionom segmentu 


\begin{tabular}{|c|c|c|c|}
\hline 16 bita & 176 bita & 14 bita & 82 bita \\
\hline BIC3 & INFORMACIJA & CRC & PARITET \\
\hline
\end{tabular}

Broj informacionih blokova: 272

Sl. $8 d-\operatorname{Ram} C$

Broj informacionih bita u bloku: 176

Kodna zaštita: CRC na 2. sloju i horizontalni paritet

CRC: $g(x)=x^{14}+x^{11}+x^{2}+1$ (14 bita)

Broj bita horizontalnog pariteta: 82

Ukupni broj blokova: 272

Vremenska dužina rama: 4,896s

Broj prenesenih blokova u jedinici vremena: 55,6 blok/s

Efektivna brzina prenosa informacije u DARC kanalu: 9778 b/s $(61,1 \%)$

u L2-bloku. Na slici 9 prikazana je struktura servisnog kanala. L3-blok servisnog kanala sadrži zaglavlje veličine 3 bajta i 19 bajta podataka. Maksimalna veličina poruke u servisnom kanalu je 304 bajta.

Mrežne i servisne informacije $u$ SeCh kanalu sadrže identifikacione parametre države, mreže, predajnika i kanala prenosa, zatim podatke o servisu, datumu, vremenu, prostornoj poziciji predajnika, alternativnim frekvencijama, organizaciji kanala, budućim aplikacijama, itd.

Kanal kratkih poruka SMCh uglavnom se koristi za prenos podataka u realnom vremenu. Kao i u servisnom kanalu formira se više L3-blokova veličine 22 bajta (ili 176 bita) što odgovara informacionom bloku L2-bloka. Za razliku od $\mathrm{SeCh}$ veličina zaglavlja je 2 bajta, a podaci su smješteni u 20 bajtova. Na slici 10 prikazana je struktura kanala kratkih poruka. Ovaj kanal je kompatibilan sa brzim informacionim kanalom (FIC - Fast Information Channel) DAB (Digital Audio Broadcasting) sistema. Iz sloja prenosa se kratka poruka podataka maksimalne dužine 127 bajta sa L4-zaglavljem transformiše u više L3-blokova. L4-zaglavlje, zavisno od namjene, može da ima promjenljivu dužinu u rasponu od 3 do 7 bajta.

U zaglavlju L3-bloka nalazi se CRC dužine 6 bita, a generatorski polinom je oblika $g(x)=x^{6}+x^{4}+x^{3}+1$.

Kanal dugih poruka LMCh koristi se za prenos paketa poruke velike dužine iz višeg sloja. Kao i u prethodnim kanali-

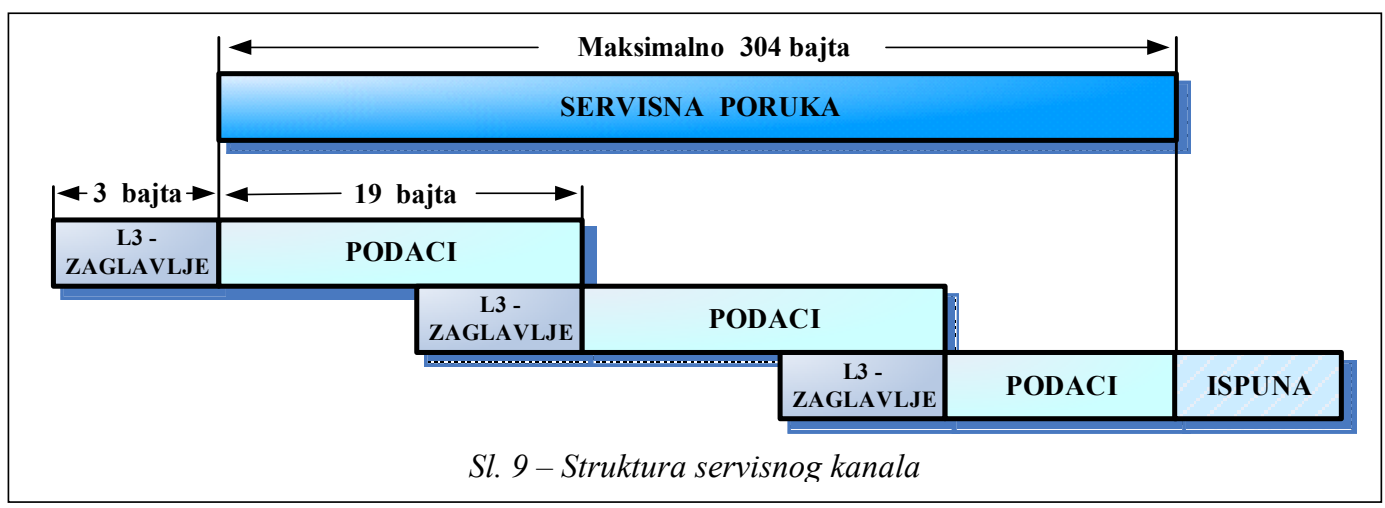




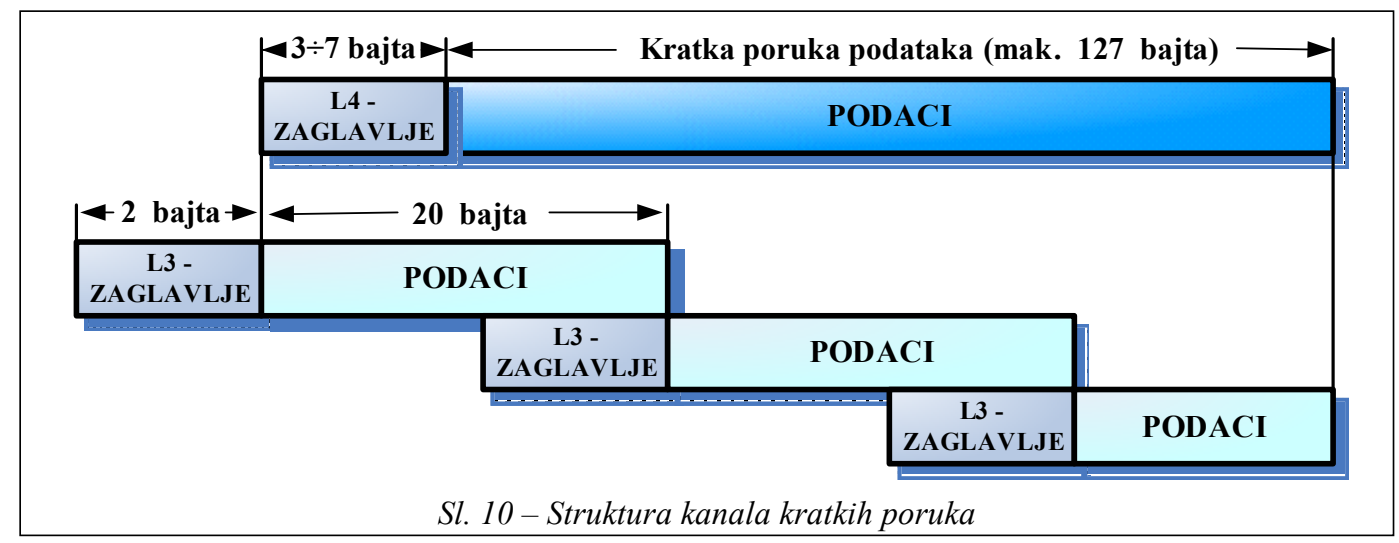

ma formira se više L3-blokova veličine 22 bajta (ili 176 bita), što odgovara informacionom segmentu L2-bloku. Zaglavlje je veličine 2 bajta, a podaci se smještaju u 20 bajtova. Na slici 11 prikazana je struktura kanala dugih poruka. Iz sloja prenosa duga poruka podataka maksimalne dužine 255 bajta sa L4-zaglavljem transformiše se u više L3-blokova. L4zaglavlje zavisno od namjene može da ima promjenljivu dužinu u rasponu od 4 do 7 bajta. U zaglavlju L3-bloka nalazi se CRC dužine 6 bita sa generatorskim polinomom oblika $g(x)=x^{6}+x^{4}+x^{3}+1$.

Ovaj kanal koristi se za transport sledećih servisa:

- radio-prenos vijesti (elektronske novine itd.);

- prenos pošte (X400);
- prenos sa visokim garantovanim protokom (slike, zvuk, govorne poruke);

- transver datoteka (faks, finansijski podaci, itd.);

- adresirani tekst i grafičke poruke (saobraćajne informacije, gradski saobraćaj, itd.) itd.

Kanal izvornih blok-poruka BMCh sadrži osam potkanala (0-7) koji se koriste za jednostavne blok-bazirane protokole. Unos podataka je direktan. DARC forum je nadležna institucija koja definiše raspodjelu potkanala.

Struktura BMCh kanala prikazana je na slici 12. Zaglavlje je veličine 1 bajt, dok se podaci formiraju od blokova aplikacije ili rama za sinhronizaciju poruke. Maksimalan broj blokova je 32767, a njihova veličina od 19 do 22 bajta, zavisno od vrste potkanala.

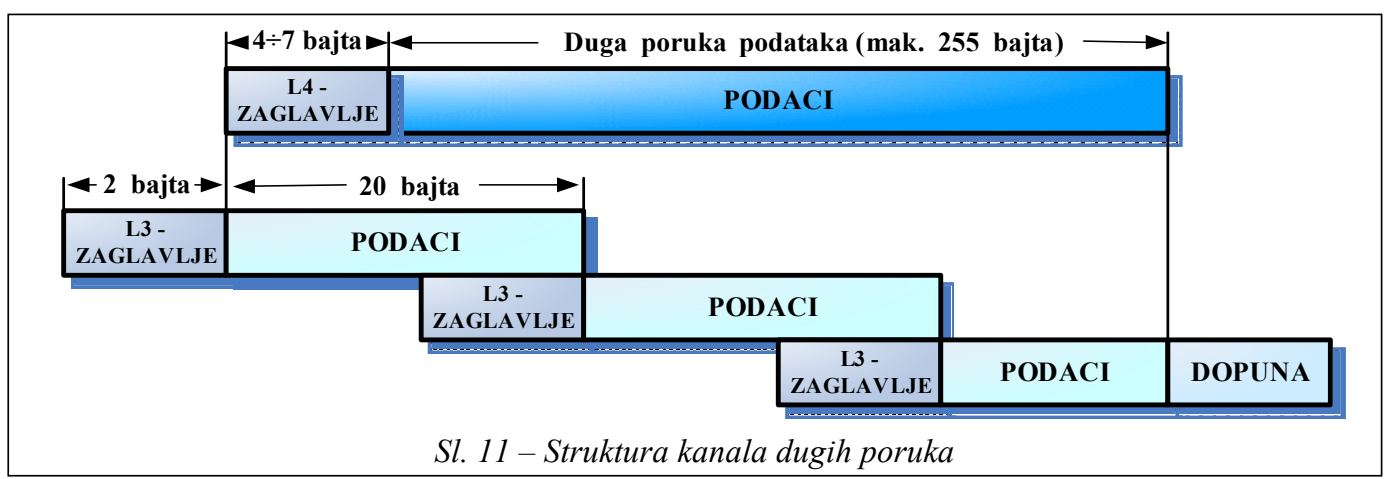




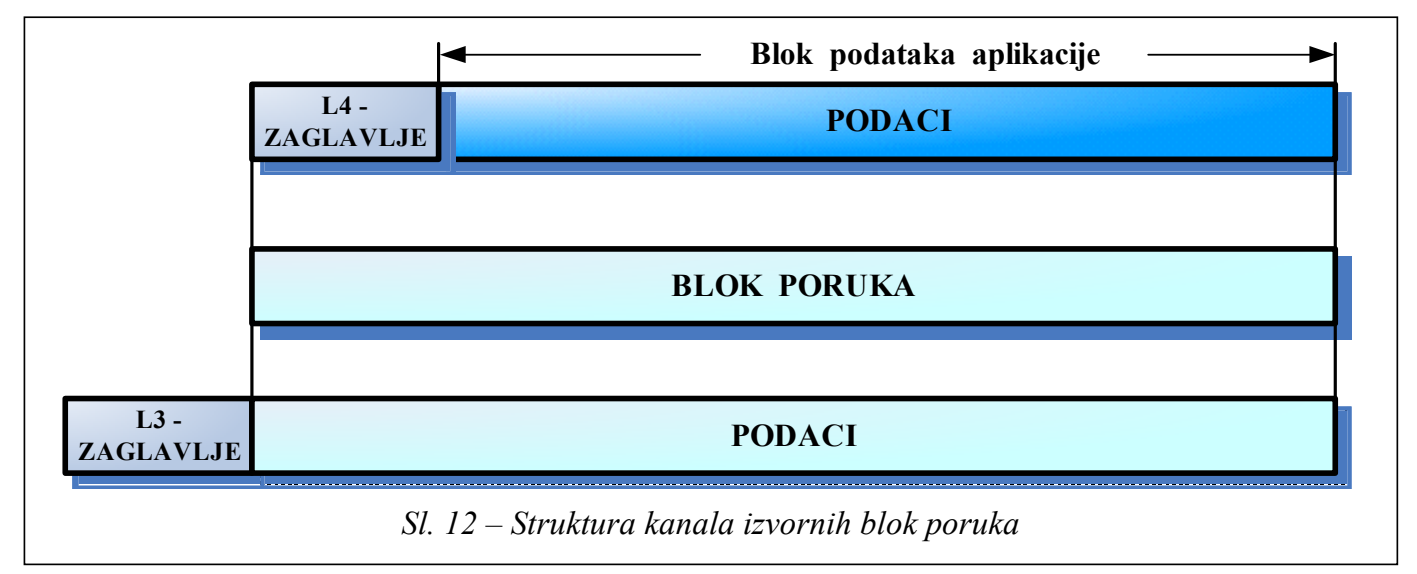

\section{Sloj prenosa (4. sloj)}

Sloj prenosa služi za adresiranje $s$ kraja na kraj i omogućava korisniku izbor aplikacije. U njemu se formiraju ili izdvajaju dvije vrste paketa (dugi i kratki). Dugi paket može da ima maksimalnu dužinu od 255 bajta, a maksimalna dužina kratkog paketa je 127 bajta. Zaglavlje L4 je promjenljive dužine i zavisi od logičkog kanala 3. sloja u koji se paket smješta. Ona varira od 2 do 7 bajta. Ovi paketi dijele se u blokove i prenose sloj niže. Najčešća dužina bloka je 20 bajta.

\section{Sloj sjednice (5. sloj)}

Sloj sjednice je najviši sloj DARC-a koji povezuje aplikacije u formi fragmentiranih datoteka i velikih paketa (sli- ka 13) sa ostalim slojevima sistema. Drugim riječima, prilagođava izvorne poruke za ulazak i izlazak iz sistema.

$\mathrm{Na}$ slikama 14 i 15 prikazane su osnovne strukture fragmentacije L5 paketa i datoteka.

Unutar ovog sloja na strani servera (predaje) provode se sledeće procedure:

- ulazak izvornih podataka u sistem;

- kompresija podataka (ako se zahtjeva);

- unos koda i prefiksa datoteke TLV (Type, Length, Value);

- dodavanje CRC (ako se zahtjeva);

- fragmentacija podataka (ako je potrebno).

$\mathrm{Na}$ strani prijemnika poduzimaju se sledeće procedure:

- defragmentacija podataka;

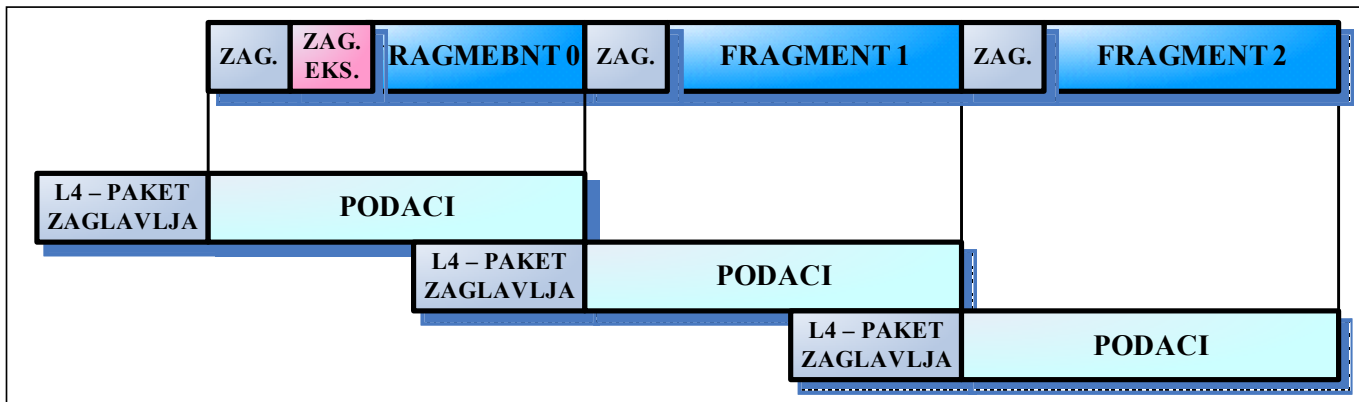

Sl. 13 - Struktura osnovne fragmentacije 


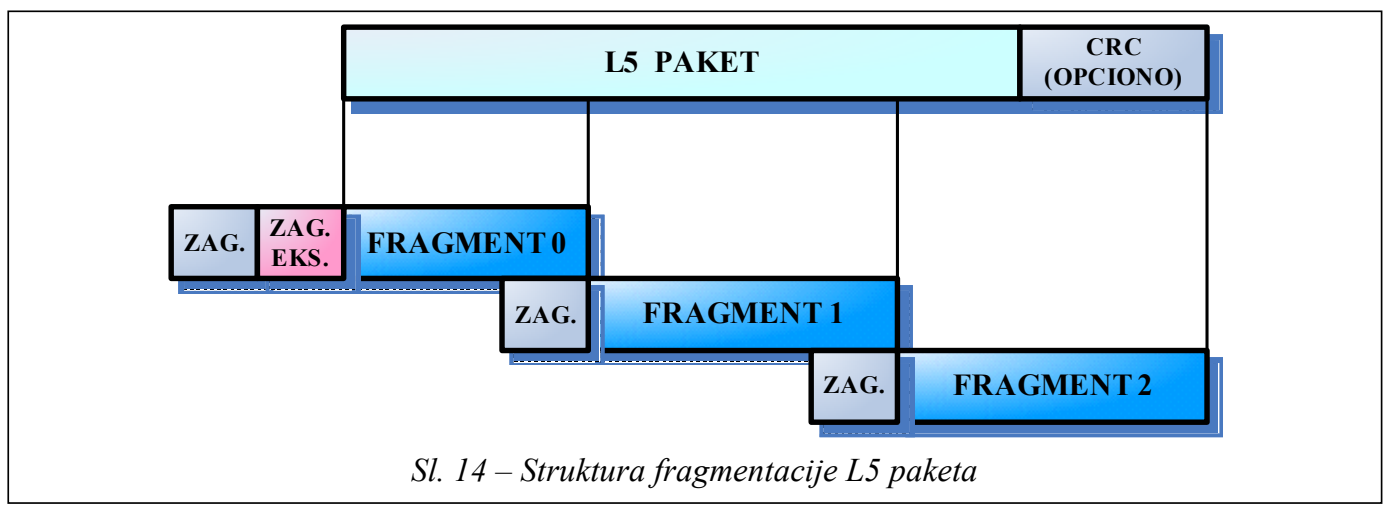

- provjera CRC-a;

- dekodiranje datoteka TLV;

- dekompresija podataka;

- prikaz ili primjena izvornih informacija.

\section{Elementi DARC mreže}

U prethodnom prikazu data je struktura DARC mreže sa svojim elementima i međusobnim vezama. Položaj elemenata [3] u strukturi definiše njihovu ulogu i parametre koje treba da zadovolje.

Prvi element u mreži je server davaoca servisa SPS na kojem se nalaze servisi u formi datoteke, elektronske pošte, Weba, podataka i drugih formi. Izlaz sa servera mora da bude potpuno kompatibilan sa
DARC mrežom i na njemu može da se vrši kompresija, fragmentacija i zaštita (šifrovanjem) podataka. Pored toga, na serveru se obavlja pojedinačno i grupno adresiranje korisnika, upravljanje pristupom i transmisiom podataka, a u posebnom slučaju i upravljanje opremom predajnika TSE, odnosno DARC koderom. Hardverska konfiguracija najčešće je zasnovana na PC platformi sa Windows ili Linux operativnim sistemom, sa više različitih priključaka (RS232, USB i Ethernet).

Drugi element u mreži predstavlja server mreže NWS, koji je preko prenosnih veza povezan sa ulazne strane sa serverom davaoca servisa, a sa izlazne strane sa opremom predajnika. Njegova primarna funkcija je prenos podataka između ta dva kraja.

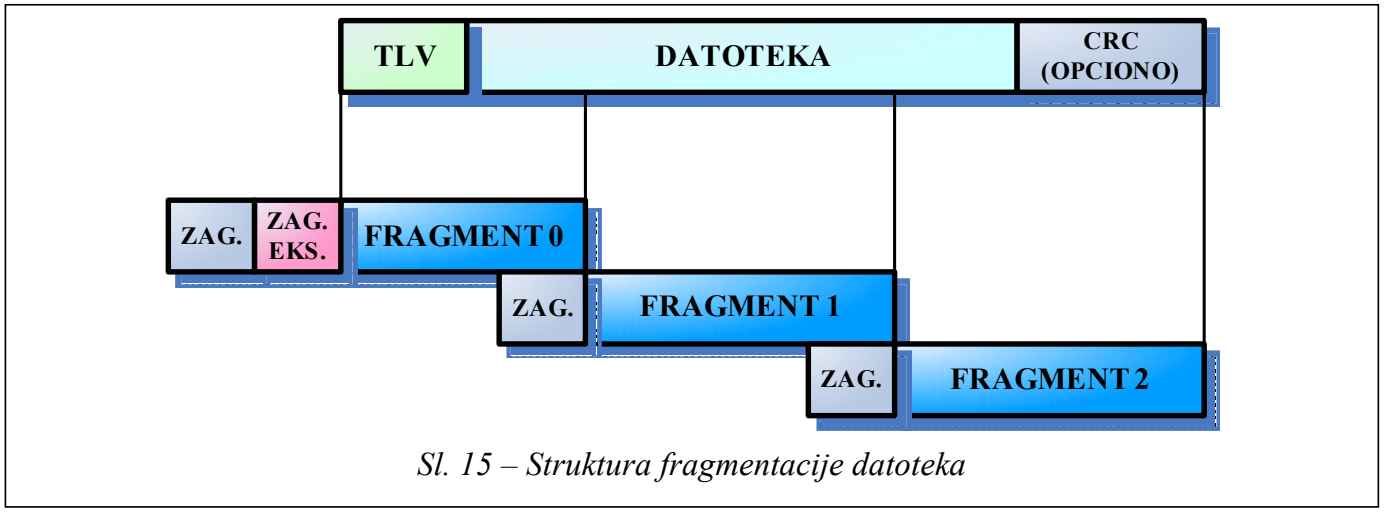


Izlaz iz servera su poruke 3. sloja DARC-a kao i poruke pratećih funkcija kojima se upravlja radom mreže i priključenih elemenata. NWS prosleđuje dva glavna servisa SPS-a, i to datoteke servisa radio-difuzije i servis prenosa podataka u realnom vremenu. Za prvi servis datoteke se prvo učitavaju sa SPS-a u NWS, zajedno sa setom upravljačkih direktiva, kao što su zahtjevi kvaliteta, adresiranje ili planovi radio-difuzije, a potom se prosleđuju do radio-difuznih predajnika. Za drugi servis, koji je vremenski kritičan, ostvaruje se direktni kanal (tunel) kroz NWS između SPS-a i prijemnog terminala sa minimalnim kašnjenjem. $U$ tabeli 3 navedene su dodatne funkcije koje obavlja server mreže.
$\mathrm{Na}$ isti način može se formirati više hijerarhijskih uređenih mreža sa NWS, tako da na državnom nivou može da postoji jedna centralna mreža sa više regionalnih i lokalnih podmreža.

Treći element su prenosne veze koje povezuju sve elemente unutar DARC mreže. Generalno, postoji šest vrsta međusobnih veza, ako se posmatraju funkcije koje one obavljaju. Komunikacija može da bude jednosmjerna (simpleksna) ili dvosmjerna (dupleksna). Jednosmjerna komunikacija je sam prenos DARC signala između radio-difuznih predajnika i prijemnika. Međutim, ovaj tip prenosa može se primijeniti i za udaljenu vezu NWS sa TSE, s tim da se gube dinamičke funkcije upravljanja i kon-

Tabela 3

\begin{tabular}{|l|l|}
\hline \multicolumn{1}{|c|}{ Funkcija } & \multicolumn{1}{c|}{ Opis } \\
\hline Pristup i kontrola sintakse & $\begin{array}{l}\text { Ostvaruje kontrolu pristupa mreži i kontrolu i korektnost sintakse ulaznih } \\
\text { podataka. Informacije koje dolaze na NWS mogu biti identifikator servisa, } \\
\text { kod oblasti prekrivanja, tekuće vrijeme, itd. }\end{array}$ \\
\hline Korisnička obrada podataka & $\begin{array}{l}\text { Vrši konverziju poruka 5. sloja u poruke 4. sloja, skremblovanje podataka za } \\
\text { neke servise, itd. }\end{array}$ \\
\hline $\begin{array}{l}\text { Administracija davaoca } \\
\text { servisa }\end{array}$ & $\begin{array}{l}\text { Obezbjeđuje informacije o davaocima servisa i vrši kontrolu kapaciteta } \\
\text { logičkih kanala za svaki servis. }\end{array}$ \\
\hline Rezervacija & $\begin{array}{l}\text { Dozvoljava davaocima servisa da emituju podatke u rezervisanom terminu, } \\
\text { i preuzimaju veliku količinu podataka na server mreže. }\end{array}$ \\
\hline Kontrola prioriteta & Ostvaruje kontrolu prioriteta između servisa i poruka. \\
\hline Kontrola protoka & Onemogućava preopterećenje TSE. \\
\hline Multipleksiranje & $\begin{array}{l}\text { Vrši objedinjavanje, smještanje i razvrstavanje poruka različitog prioriteta u } \\
\text { memoriju servera. }\end{array}$ \\
\hline Adresiranje i umrežavanje & $\begin{array}{l}\text { Omogućava adresiranje i prateće aktivnosti pri usmjeravanju poruka- } \\
\text { podataka od servera ka TSE. }\end{array}$ \\
\hline Sistemsko vrijeme - sat & Omogućava sinhronizaciju svih dijelova mreže od strane NWS. \\
\hline Kontrola rada & Vrši superviziju svih aktivnosti na mreži od strane NWS. \\
\hline
\end{tabular}

Hardverska konfiguracija servera najčešće je zasnovana na PC platformi sa Windows ili Linux operativnim sistemom. Pristup serveru vrši se preko Ethernet, USB, RS232 ili modemskog priključka. Putem dvostrane komunikacije NWS istovremeno može da upravlja radom više servera (SPS) i kodera (TSE). trole, koje zahtijevaju povratnu petlju. Dvosmjerna komunikacija je prisutna kod svih ostalih veza, a može se realizovati na više načina žičnim putem (bakarnim ili optičkim kablovima) ili bežičnim putem (radio, radio-relejne ili satelitske veze). Tehnologija prenosa može da bude modemski prenos, Ethernet, ISDN, X.25, itd. 


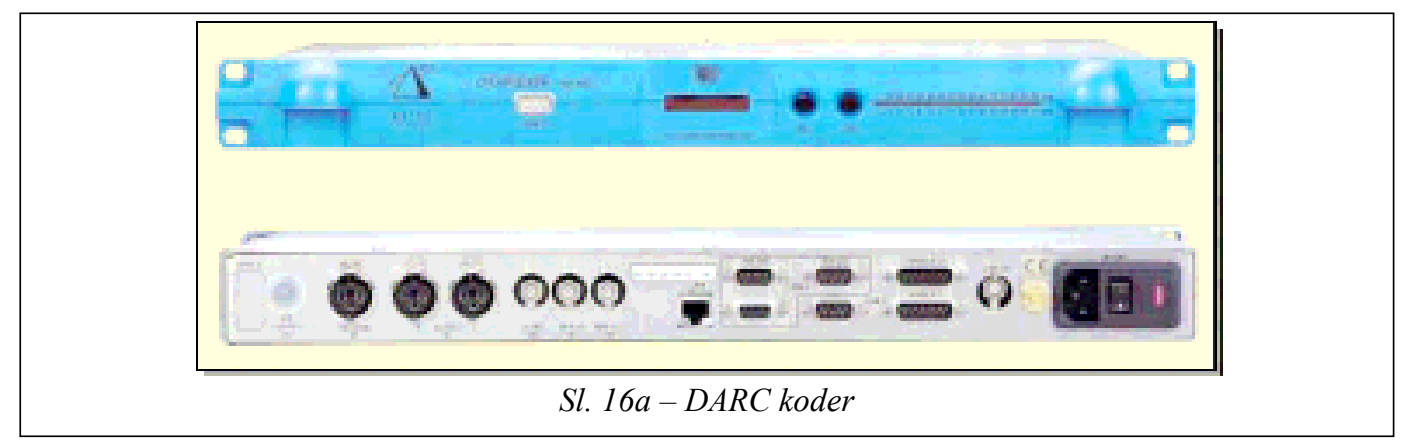

Četvrti element predstavlja oprema predajnika (koderi) [4] koja ima više funkcija. To su funkcija mrežne komunikacije; funkcija komunikacije sa NWS ili sa lokalnim izvorom podataka; funkcija multipleksiranja sa različitih izvora podataka (NWS, lokalni izvori) na nivou 4. sloja i funkcija demultipleksiranja poruka 4. sloja na poruke 3. sloja; funkcija kodiranja i modulacije DARC nosioca na FM radio-difuznom predajniku; funkcija kontrole i monitoringa opreme predajnika i emitovanog signala.

Na slikama 16a i 16b prikazan je jedan tip DARC kodera i FM radio-difuznog predajnika. Koderi najčešće imaju
RS232, BNC i Ethernet priključke, preko kojih se vrši dotur poruka za DARC i programiranje i upravljanje radom.

Peti element su korisnički prijemnici. Mogu se realizovati na više načina, bilo da su namjenski razvijeni ili da se vrši dogradnja postojećih prijemnika sa DARC dekoderom. U oba slučaja postoje priključci (RS232 ili PCMCIA) preko kojih se prijemnici povezuju sa spoljnim terminalnim uređajem. Kao terminal mogu da služe razne varijante računara (stone, mobilne, prenosne), GPS prijemnici, kontroleri, itd. Na slici 17 prikazane su neke varijante korisničkih prijemnika.

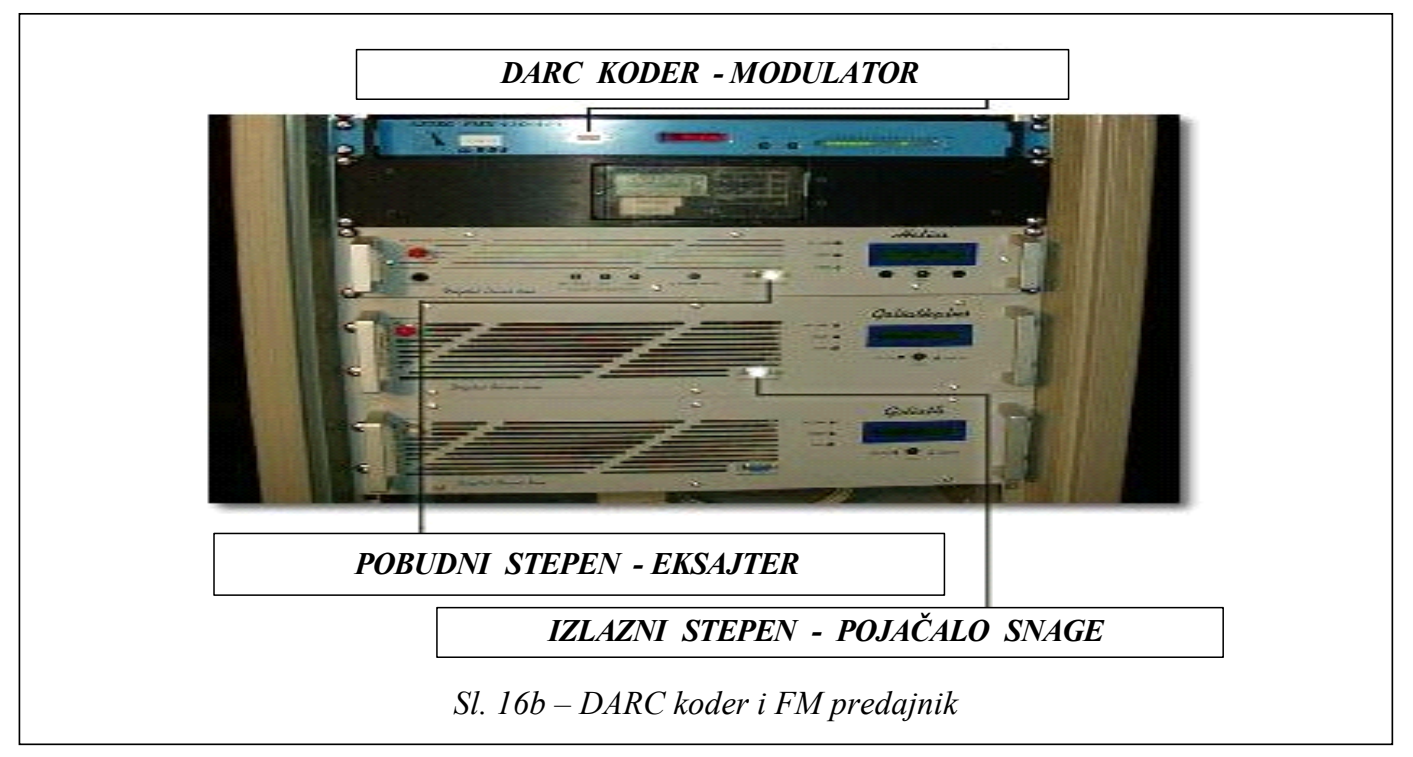




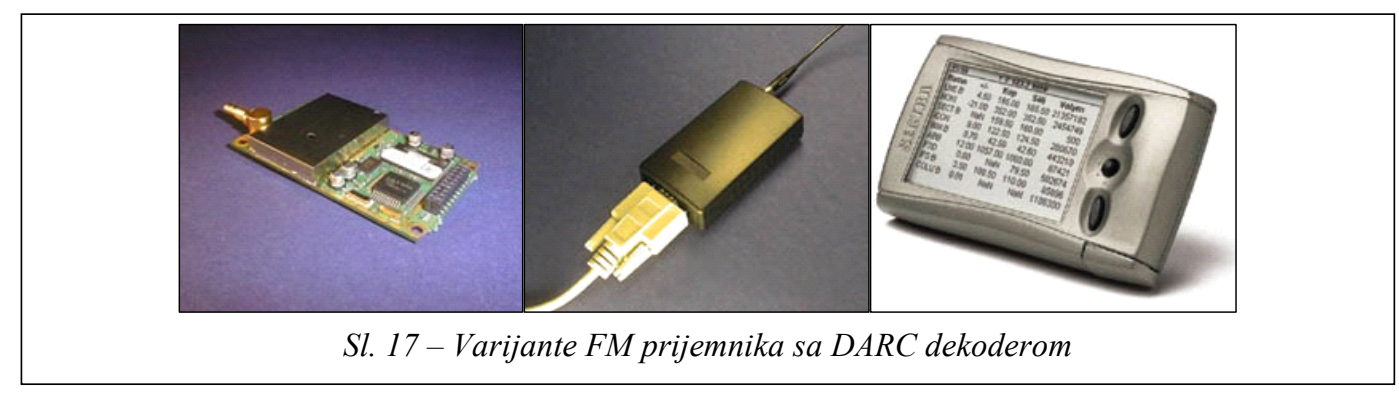

\section{Funkcije kontrole pristupa DARC mreži}

Ovako složena i široko rasprostranjena mreža mora da posjeduje odgovarajući sistem kontrole pristupa radi sprečavanja neautorizovanog korištenja ili degradacije sistema. Kontrola pristupa vrši se kroz tri funkcije: zaštitu informacije, kontrolu ovlaštenja i upravljanje ovlaštenjem.

Prva funkcija primjenjuje se na korisni (informacijski) dio poruka DARC servisa. U ovom slučaju koristi se tehnika skremblovanja. Moguća su tri režima rada:

1. Neskremblovani režim omogućava korištenje servisa svima koji imaju adekvatnu standardizovanu opremu.

2. Skremblovani režim sa unaprijed specificiranom kontrolnom riječi (CW Control Word) koja je stalno instalisana u prijemniku.

3. Skremblovani režim sa kontrolnom riječi $(\mathrm{CW})$ koja se redovno mijenja. U ovom slučaju kontrolna riječ se šifruje i šalje u prijemnik putem poruke kontrole ovlaštenja.

Prvi režim rada najčešće je zastupljen, jer predviđa slobodno korištenje servisa i korisnici nisu autorizovani. Druga dva režima su restriktivnija, jer predviđaju autorizaciju korisnika i selektivno korištenje servisa. Sam postupak skrem- blovanja vrši se tehnikom sabiranja po modulu 2 bita korisne informacije sa pseudoslučajnom binarnom sekvencom (PRBS - Pseudo-Random Binary Sequence). Generator pseudoslučajne binarne sekvence definisan je u standardu ETS300174. Skremblovanje se ne odnosi na redundantni dio poruke (zaglavlje, preambula, paritet, $\mathrm{CRC}$, itd.).

Druga funkcija - kontrola ovlaštenja sastoji se od emitovanja uslova za pristup servisu primjenom šifrovane zaštitne riječi, preko koje autorizovani prijemnik može vršiti deskremblovanje korisne poruke.

Treća funkcija - upravljanje ovlaštenjem sastoji se u distribuciji pretplatničkih ovlaštenja. Ona mogu da budu po temama ili klasama, po plaćenom iznosu ili impulsu za odgovarajući program, po servisu ili zakupljenom vremenu, itd. Složenija rješenja predviđaju korištenje pametnih (smart) kartica na korisničkoj strani.

\section{Primjena DARC servisa}

Primjena DARC servisa zasniva se na sledećim prednostima: koristi se postojeći FM radio-difuzni sistem; gotovo stopostotno višestruko pokrivanje nacionalne teritorije radio-difuznim signalom, a time i DARC servisom; mala finansijska ulaganja i visok odnos efikasnost/cijena; brzina prenosa informacije zodovoljava ve- 
ćinu primjena koje se odvijaju u realnom vremenu; mobilnost korisnika; pasivan prijem (simpleksni prenos); odvojena i raznovrsna distributivna mreža; gotovo idealan servis za sve vrste simpleksnog prenosa; otvorenost standarda.

Navedene prednosti pružaju raznovrsnu primjenu DARC servisa, koje se generalno mogu razvrstati u tri grupe:

- primjena DARC-a u funkciji podrške FM radio-difuziji;

- komercijalna primjena DARC-a;

- specifične primjene DARC-a.

Ova poslednja grupa odnosi se, pored ostalog, i na segment vojne primjene. $\mathrm{U}$ tom segmentu posebno su značajne sledeće aplikacije [5]:

- primjena DARC-a za diferencijalni GPS (DGPS/RTK);

- primjena DARC-a za prenos informacija VOJIN-a;

- primjena DARC-a za prenos tačnog sistemskog vremena;

- primjena DARC-a za prenos meteoroloških podataka;

- primjena DARC-a za prenos kratkih poruka i elektronske pošte, itd.

Interesantan primjer primjene za vojne svrhe predstavlja sistem LuLIS (Švedska) [6], [7]. To je informacioni sistem VOJIN-a za rano uzbunjivanje, koji pokriva teritoriju Švedske i drugih zemalja. Ovaj sistem prezentira trenutnu situaciju u vazdušnom prostoru i daje prethodna obavještenja za sve korisnike na bilo kom dijelu teritorije ili vazdušnog prostora. Pored toga, daje informacije o tragovima; podatke o zabranjenim zonama i svim koridorima leta; zone za PVO jedinice i korekciju za DGPS/RTK. Sve informacije su zaštićene i prenose se u realnom vremenu. Sistem šalje tekstualne poruke, a sistemsko vrijeme je visoke tačnosti.

Odlika ovog sistema je: gotovo trenutna reakcija na promjene u vazdušnoj situaciji (malo kašnjenje toka informacije od izvora do korisnika); mobilnost korisnika; velika fleksibilnost; otpornost sistema na ED; krajnji korisnici su radio-pasivni, itd.

\section{Zaključak}

Performanse DARC servisa konvencionalne FM radio-difuzije omogućavaju vrlo široku primjenu, kako u civilnom, tako i u vojnom domenu. Osnovna prednost ogleda se u korištenju postojećih FM radio-difuznih mreža, punom prekrivanju teritorije, jednostavnosti, fleksibilnosti, niskoj cijeni ulaganja, zadovoljavajućoj brzini i kvalitetu prenosa informacija, mobilnosti prijema i radio-pasivnosti korisnika.

Literatura:

[1] ETSI EN 300751 V1.2.1 (2002-09) Radio broadcasting Systems; DAta Radio Chanel (DARC).

[2] Roland Andersson: The possibilities of using DARC/ /SWIFT for datacasting, MIRS 1998.

[3] www.darc-forum.com/system.htm

[4] www.audemat-aytec.com;

[5] KP-32/99 - ppuk. Mladen Manjak, Primjena radio-difuzne mreže SRJ za prenos podataka od interesa za VJ.

[6] www.axentia.se

[7] www.sectra.se 